\title{
The Description of Teachers' Use of Reinforcement in English Language Classes
}

\author{
Ndegwa Grace Konyu \\ Dr. Lucy Wathika \\ Dr Josephine Khaemba \\ Department of Literature \\ Languages and Linguistics \\ Egerton University \\ Kenya
}

\begin{abstract}
The purpose of the study was to describe teachers' use of reinforcement in English language classes. The study was guided by Gardner and Lambert's Socio-Educational theory of second language acquisition. The study was carried out in selected secondary schools in Nakuru town. It used descriptive research design. Stratified random sampling was employed to select the four schools while simple random sampling was used to choose one stream in form two, three and four in each school for observation. It resulted in eight observational schedules. The study sample of 60 students in form 2-4 and 8 teachers of English was purposively selected for interviews. A total number of 353 learners were observed. The study used interviews, audio recording and Structured Observational Schedules for data collection. The data was presented in form of tables, figures and verbatim transcript excerpts used for exemplification and illustration in a qualitative explication. The findings of the study revealed that second language learners' performance in English is greatly influenced by teachers' use of reinforcement. Moreover, the findings of this study proved that teachers of English giveunguardedpraises, negative statements and criticisms to English second language learners.This study is an important contribution to the field of Second Language Acquisition Theory and practices with regard to offering information and insight into reinforcement, motivation and attitude in practical language acquisition and learning in the classroom situation. These findings are useful in the improvement of second language learners' performance in English. Teachers of English will also acquaint themselves with effective use of positive verbal reinforcement (general praise, ability praise and effort praise) which works as a driving and motivational force on learners' acquisition and use of English language.
\end{abstract}

Keyword: Learner, Learner's performance, Positive reinforcement, Reinforcement schedules, Second language acquisition.

\section{Introduction}

The role of reinforcement on second language learners' performance in English is very significant because it enhances the learning of a second language. English has a prestigious status and is the most common second language used by most communities worldwide (Crystal, 2015).In Kenya, it serves as the most important tool to attain both national and curriculum goals of education as enshrined in Vision 2030 (Gathua, Kiptiony \& Somba, 2012). In order to study English as a second language and be successful in it, learners must be facilitated to obtain the four language skills. They are listening, speaking, reading and writing (Wyatt, 2009). According to Wheeler (2009), the teacher improves a student's behaviour by creating a supportive learning environment by positively reinforcing the desired behaviour. Reinforcement on the second language during classroom teaching is one of the most significant factors which play a positive role in second language learning by enhancing the performance of the language (Fromkin et al., 2018). According to Zua (2008), the emotional bonding between students and teachers ought to be built. Students are anticipated to be at ease with their teacher of English and be certain that he/she will correct them if at all, they make mistakes. Bonieckiand Moore (2010) further affirm that teachers have the ability to reinforce learners' behaviour extrinsically through praise or tangible prizes. Systems of formal praise enhance inherent motivation to develop learners' behaviours (Wheatley et al., 2009). The linguistic repertoire of secondary school students in Nakuru town is that of multilingualism which supports that Kenya is highly multilingual. The multilingual students are the majority at 69.32 percent that speak English, Kiswahili, Mother tongue and Sheng-slang (Oduor, 2016).English language in Kenya serves as lingua franca that enables communication among people depending on their exposure and level of education (Kaviti, 2018). 
Students' oral proficiency in English is affected much by their communicative patterns. Students have expression difficulties in their spoken English because they mostly use Kiswahili and Sheng in their oral interactions in all the domains in which they are by themselves. This greatly limits their opportunities to practice speaking in the school setting. As a result, this affects their oral proficiency in the language (Oduor, Ibid).

Despite the importance of English language in Kenya, performance in it as a subject in the national examinations has remained far below the expected standards. A report from the Nakuru Town East and West Sub-County Education offices indicates that the percentage of learners, who perform below average in English in the K.C.S.E examination in the town, over the years, has been increasing. Learners' performance in English subject is assessed, measured and evaluated in the mastery of listening, speaking, reading and writing skills tested in functional skills, comprehension, literally appreciation, grammar, imaginative composition and essays based on set texts.

Table 1 indicates the learners' registered performance in English subject as a second language out of 12 points for five consecutive years. The performance is inconsistent, that is, improving one year and deteriorating the next. The status shows that as time goes the number of learners who fail in the subject increases. It is in this respect that the study sought to investigate the description of teachers' use of reinforcement in English language classes.

Table 1: K.C.S.E English Subject Performance

\begin{tabular}{|l|l|l|l|l|l|}
\hline Year & $\mathbf{2 0 1 7}$ & $\mathbf{2 0 1 6}$ & $\mathbf{2 0 1 5}$ & $\mathbf{2 0 1 4}$ & $\mathbf{2 0 1 3}$ \\
\hline Mean score & 5.484 & 6.346 & 5.633 & 6.118 & 5.695 \\
\hline Deviation & -0.862 & +0.713 & -0.485 & +0.423 & \\
\hline
\end{tabular}

(Source: Ministry of Education, Science and Technology, 2018).

English is the language of instruction in Kenyan secondary schools; hence the performance in it determines the achievement in other subjects except for Kiswahili and other foreign languages. Despite that, there is worrying trend of poor performance of English language in K.C.S.E examination in Nakuru town. There are few studies in Second Language Acquisition that have focused on the influence of reinforcement on second language learners towards the improvement of competence. Reinforcement has always been considered important in education theory and practice; however, little focus worldwide has been given to praise and motivation, especially in Second Language Acquisition research.

\section{Literature Review}

\section{Reinforcement}

Reinforcement in behavioural psychology refers to the consequence applied that will strengthen a person's future behaviour whenever that behaviour is preceded by a particular antecedent stimulus (Reeves, 2017). Reinforcement is very important in the achievement of academic excellence. More students of English as a vital second language can be inspired if teachers of English embrace important concepts of reinforcement. It is maintained that for a consequence to be called a reinforcer, there must be an indication that it strengthens behaviour for a specific individual. Reinforcement happens when an event following a reaction, rises an organism's propensity to make that response (Nnachi, 2007). The stimulus-response theorists believe that for language learning to occur, the teacher has to motivate students by the use of reinforcement techniques. This study found out that teachers' verbal praise is a reinforcer on second language learners' performance in the English language. In operant conditioning, reinforcement is classified into positive reinforcement and negative reinforcement.

\section{Positive Reinforcement}

Positive reinforcement involves a positive reinforcer which is the motivation that raises the possibility of a behaviour happening when it is added to a condition. For instance, when you exchange jokes and the audience laughs, the more the exchanging jokes behaviour continues. A study by Conroy et al. (2009) established that teachers could advance their general classroom environment, in addition to rising positive interactions with learners by professionally implementing positive reinforcement. This study ascertained that positive reinforcement of learners is a powerful tool in the improvement of performance in the use of English language in selected secondary schools in Nakuru town, hence may increase the opportunity of acquiring communicative competence in the language.

\section{Schedules of Reinforcement}

A schedule of reinforcement is a set of rules or procedures that a teacher during classroom activities follows when delivering reinforcers (Hirst, Lockenour \& Allen, 2019). For instance, reinforcement can be given to a learner after every accurate response to a question based on the protocol set by the teacher. Continuous schedule and intermittent schedule are the two types of reinforcement schedules. 
A continuous schedule of reinforcement happens when reinforcement is delivered after every single target behaviour while an intermittent schedule of reinforcement occurs when reinforcement is delivered after some behaviours or answers but by no means after each one. Additionally, continuous reinforcement schedules are frequently used by teachers when teaching new behaviours, while intermittent reinforcement schedules are commonly used by teachers when maintaining previously learned behaviours (Martin \& Pear, 2016).

Nwankwo (2002) says that several schedules of reinforcement affect the learning and final performance level attained. Intermittent reinforcement schedule is resistant to extinction (Weiten, 2007). If the teacher of English uses intermittent reinforcement schedule, the students can keep making efforts to answer questions and maintain a high level of academic performance because they can be reinforced any moment as in variable ratio schedule or after varying lengths time as in variable interval schedule (Slavin, 2009).

Okpala (2000) notes that continuous and intermittent reinforcement schedules produce important differences in performance. These differences are most apparent at three stages in learning. First, during the initial development of a response, continuous reinforcement is preferable because it accelerates this early performance and produces high rates of response. The implication of the above in a second language situation is that if a teacher introduces an entirely new topic, he/she should employ continuous schedule to increase the arousal level of the students as regards internalising the topic. After students have been introduced to the topic, the ESL teacher goes further to impart the various areas of the topic on the learners. He/she uses an intermittent reinforcement schedule for response maintenance because it increases resistance to extinction. Both continuous and intermittent reinforcement schedules play key roles in learning English as a second language. These findings relate to the present study, which looked at the time second language learners received reinforcement and how it affected their level of performance.

\section{Reinforcement of Second Language Learners of English}

Reinforcement is very important in the achievement of academic excellence worldwide. Odima's (2015) study looked into the influence of teaching on the acquisition of English language skills in primary schools in Busia County, Kenya where he collected data using structured questionnaires, interview schedules and descriptive research design to analyse the data. Based on the results of his study, he acknowledges that teachers of English play a major role in helping learners to gain, practise language skills and develop proficiency. Chondhury (2014) agrees that the main responsibility of all teachers of English is to help all learners in the development of their capability to write and speak better language. The current study found out that more learners of English has a second language got motivated when teachers of English embraced important concepts of reinforcement.

According to the UNESCO education report, examination results are prejudiced by factors other than teaching, including student skills, expectations, motivation, parental background, peer pressure, curriculum structure, school organizational resources and culture. Teachers' influence on students' performance is cumulative, where their performance is influenced not only by current teachers but also by former ones (Wanzala, 2017). Improving learners' performance in English means that their national examination results in K.C.S.E will also be enhanced. The current study found out that teachers' positive verbal praise reinforcement enhances learners' performance in the English language.

Kotut (2016) carried out research on factors influencing the performance of English as a subject in Kenya Certificate of Primary Education in Nakuru Town, East sub-county. The findings indicated that the respondents agreed and/or strongly agreed that to improve students' attitude in learning of English, various rewards are given to excellent pupils. Majority of the respondents strongly agreed and/or agreed (92.4\%) that student's attitude in the learning of English which is achieved through positive reinforcement by teachers of English, greatly determines their success in learning. It was in agreement that the teachers support weak students by building their motivation in learning English. The current study established that to improve learner's motivation in the learning of English language, positive reinforcement like the use of positive verbal praise should be given to all learners of different performance levels (low-, average-, and high- scoring) which would later show a significant increase in their performance.

In a study on challenges and strategies for teachers and learners of English as a second language, Dhillion and Wanjiru (2013) studied the reinforcement strategies for teachers and learners of English in an urban primary school in Kenya. One of their outcomes showed that positive reinforcement was more significant and intricate often used by the majority of teachers in their classroom management. In addition, the results of their study displayed that forms of rewards and appraisal are good in reinforcing learners. These findings relate to the present study which looked into the role of reinforcement on second language learners' performance in English in selected secondary schools in Nakuru town. While their study looked into forms of rewards and appraisal, the current one sought to investigate teachers' positive verbal praise reinforcement which its findings revealed that it strengthens learners' of English language behaviours. 
Wafula, Malimbe and Kafu,(2011) carried out research on classroom management. It was to determine the state of positive reinforcement in secondary education in Kenya. The study was carried out in public secondary schools in Eldoret Municipality. They established that positive reinforcement in the secondary school class room in Kenya drives at inspiring students' positive academic achievement, teacher efficacy and effective teaching and learning. The results of their study confirm that incentives are good in comparison to those that incline to be material in nature. In fact, the latter should not be regularly used. This is because some students might do everything they can to perform a chore for the sake of the reward. They established that positive reinforcements are indispensable techniques in classroom management. While their study was on general education classroom management, the present one focused specifically on English language behaviour management on second language acquisition and use in English. It is evident from the current study that teachers' verbal praise reinforcement manages English language behaviour of learners.

With regard to the efficacy of reinforcement tactics, Oyo (2012) examined the usefulness of the rewards system in Kenyan secondary schools. The study concentrated on the assessment of how rewards have an effect on positive attitudes resulting in the advancement of school's standards in academics. The findings of their study revealed that most students prefer simple items like erasers, stickers and pencils as prizes and other classroom treats such as homework pass and computer time. Whereas the study was on prizes, the current one investigated the effectiveness of the verbal praise.

Kirui (2007) carried out an investigation on the effect of teachers' use of praise and criticism in students' learning in Moiben Division of Uasin Gishu District, Kenya. She found out that though teachers use praise and criticism in the classroom, criticisms were commonly used compared to praise. Praise encouraged students to actively participate in class by attempting questions asked, paying attention to the teacher and putting more effort into their class work. Criticism, on the other hand, had made the students get discouraged, hate the subject, and the teacher concerned, fear the teacher, get stressed, feel embarrassed, irritated, avoid questions and lack concentration. She concluded that praise enhanced learning while criticism hindered learning.

Her findings were useful for this study which also comparatively tried to find out the starring role of positive reinforcement on second language learners' performance in English. Whereas Kirui's study investigated learners in the following subject classes: English, Kiswahili, Mathematics, Chemistry, History, Business Studies and Agriculture, this study was specific to English language classes. Her study was carried out in a linguistically homogeneous area while this one was conducted in a linguistically heterogeneous area.

Njoroge (2013) looked into language learner performance and interpretation of teachers' written comments among primary school learners in Nakuru Municipality, Kenya. She found out that pupils interpret teachers' written comments in different ways. Given that she established that positive relationship exists between teachers' written comments and pupils' attitude and motivation towards learning and using the English language, it was worth considering the effect of teachers' use of verbal praise reinforcement on secondary school learners' acquisition and use of English language which was the concern in the current study.

\section{Effects of Teachers' Verbal Praise Reinforcement on Students' Learning}

Brophy (1981) contends that praise is broadly recommended method of reinforcement by teachers. It enhances intrinsic motivation. Praise is typically seen as appropriate not only because it can be an operational reinforcer but due to its provision of encouragement to learners which help them to build self-esteem and enhance teacher-student relationship. An additional specific potential advantage is that praise permits an undeviating statement of the contingency between behaviour and reinforcement. Anything characterized as positive reinforcer must proliferate the rate of behaviour; therefore, to the extent that praise is defined as a positive verbal reinforcer, it cannot have anything but enhancing effects. The current study found out that praise used by teachers enhanced learners' motivation, provided encouragement, helped build their self-esteem, self-confidence, a close teacher-student relationship and improved their performance. Praise is correspondingly considered to have valuable effects on learners' motivation, performance and self-esteem. A group of researchers and teachers assert that usually a feedback message of praise upsurges motivation and leads to improvement in students' performance (Pintrich and Schunk, 2002). Ilies and Judge (2005) confirm that feedback which encompasses praise is more actual since it causes a positive emotional reaction, which is frequently associated with improved motivation and higher goals. The effectiveness of praise is enhanced by the positive mood it creates or due to its capability to make people feel good about themselves (Jin, 2008). Additionally, due to the positive interpersonal dynamism that normally supplements praise, children may remain to display praised behaviour to withstand the attention and approval of the evaluator (Folse, 2009). In this case, motivational paybacks are purely extrinsic and quite transitory, dissipating as soon as the evaluator is no longer present to dole out approval (Chalak and Kassaian, 2010). Lastly, operant principles explain positive influence of praise on motivation. 
Based on these principles, praise is thought to upsurge the rate of behaviour because the positive know-how of being praised becomes connected with the behaviour that stimulated praise (O' Leary and O'Leary, 1977). Indeed, studies in this tradition of "The effects of praise on children's intrinsic motivation" have displayed that praising children for completing an assignment, following a rule, or paying attention to the teacher upshots in an increased rate of the desired behaviour (Drabman and Lahey, 1974). This study found out that the positive effects of teachers' verbal praise reinforcement on learners' intrinsic motivation resulted to increased frequency of English language behaviour. According to Lemlech (1999), a lot of teachers frequently use praise as a form of positive reinforcement for suitable behaviour and as a motivational tool. Many professionals agree that praising less is good since too much praise mostly unwisely applied such as praising for insignificant endeavours or weak efforts, especially in young learners' classes, can lessen student's self-motivation and suppress a student's natural curiosity. Davies (2003) states that actual praise necessities to be given genuinely and enthusiastically focused on the learners' effort in comparative to actual achievement. It is agreed that it is important to work on a positive style of praise which is more effective rather than a negative one like punishment (Cohen et al., 2005). Genuine, natural praise reassures positive self-esteem and acceptance of both self and among other learners in the classroom (Davies, Ibid). There is therefore the need for teachers of English to sincerely and credibly praise learners with correct responses which have affirmation and natural voice for their present effort and progress. This will lead to greater learners' achievement benefit results while using English language.

Occurrence of praise inclines to be positively correlated with self-perceptions of capability among school children (Abu-Mulhim, 2009). In another study by (Deci, 2000), grownups who were commended for a puzzle-completion chore spent a lot of time engaging in the same activity during a consequent free-choice session than those given no feedback. According to Baumeister et al., (1990), praise has been displayed to increase adults' performance at skilled tasks as compared to the performance of a control group. This study found out that despite teachers' of English knowledge of reinforcement, most of them downplayed it. The findings will acquaint teachers of English with positive verbal reinforcement techniques (general praise, ability praise and effort praise). The study also established that the rate of teachers' verbal praise reinforcement positively relates with different self-perceptions of interest and capability among secondary school learners in the mastery of listening, speaking, reading and writing skills tested in functional skills, comprehension, literary appreciation, grammar, imaginative composition and essays based on set texts.

\section{Effects of Verbal Praise Reinforcement in Motivating Second Language Learners}

Motivation is considered as one of the most vital factors in Second Language Acquisition (Sun, 2010). It is a kind of desire for learning. It is very difficult to teach a second language in a learning environment if the learner does not have a desire to learn a language. Gomleksiz (2001) expresses that motivation is a fundamental factor in the second language acquisition process. He further stresses that a less able student who is highly motivated can achieve greater success than the more intelligent student who is not well motivated. Unmotivated students are insufficiently involved in L2 learning and therefore unlikely to develop their L2 skills (Engin, 2009). The current study established that a less able learner who was often praised for effort became highly motivated and achieved greater success than the most intelligent learner who was seldom praised for his/her effort and was not motivated. Effective teachers encourage their students' participation in classroom discussions, welcome their contributions, and motivate them by such practices (Cazden, 2001; Stipek, 2002). However, many educators often allow their less proficient students to remain silent or to participate less than their English-fluent peers (Wilhelm et al., 2004). Baumeister's et al. (Ibid) presented evidence that praise can both facilitate and impede students' performance. This study found that effective teachers' verbal praise reinforcement encouraged their learners' participation in English language class learning activities which included: debates, discussions, dialogues, presentations, role plays, storytelling and games, welcomed their contributions and motivated them by their increased frequency of English language behaviours. Motivation is extensively accepted as one of the main factors which effect the rate and success of second language learning (Folse, Ibid). Secondly, it considers how ready and willing students are to gain more information to enhance their capacity to comprehend, write and speak the L2 (Engin, Ibid). Thirdly, it offers the primary incentive to initiate learning the L2 and later the driving force to endure the long and tedious learning process (Huang, 2007). Fourthly, it defines the level of active personal taking part in L2 learning (Warden and Lin 2000). Finally, motivation unswervingly affects how regularly learners use L2 learning strategies, how much learners interact with native speakers and how long they endure and maintain L2 Skills after language study is over (Wyatt, Ibid). This study established that teachers' verbal praise reinforcement on learners in English language directly affects their motivation and later performance and communicative use towards the establishment of competence. 


\section{Research Methodology}

The study was carried out in four secondary schools in Nakurutown where the target population was teachers and learners of the English language. This study used a descriptive research design. Stratified random sampling was used to select the four schools. Simple random sampling was used in choosing one stream in form two, three and four classes in each school for observation. A total number of 353 learners were observed. A sample population of 60 learners in form 2-4 and 8 teachers of English were purposively selected for the interview. Data collection tools used included interviews and observation. Structured interview questions which were audio-recorded and transcribed, were used for the learners' and the teachers' interviews. Non-participant observation method was conducted. The Structured Observational Schedule was used in the classroom observations in each of the four schools. Observation schedules were filled in during the observations. This study employed a qualitative method to analyse the recorded speech data that was transcribed using verbatim transcription and analysed. After being accustomed to the data, the information was reviewed and summarized under the heading of each question for proper analysis qualitatively. The researcher wrote a letter to the Nakuru County Director of Education to seek consent to do the research in the town. Permission was sought and obtained from the Principals, Heads of English Language Department and class teachers and also from the National Commission for Science, Technology and Innovation.

\section{Data Presentation And Analysis}

\section{Teachers' Use of Reinforcement in English Language Classes}

The objective of the study was to describe teachers' use of reinforcement in English language classes. Table 2 shows the frequency of praise used by teachers of English in classroom observation considering the learners' non-verbal communication reactions towards teachers' use of verbal praise reinforcement.

Table 2: Frequency of Praise Used by Teachers of English in the Classroom

\begin{tabular}{|c|c|c|c|c|}
\hline Teacher & Secondary school & Category & Types of Praise & Total \\
\hline \multirow{3}{*}{ Teacher 1} & \multirow{6}{*}{ A } & \multirow{6}{*}{ Boys' Boarding } & General praise & 10 \\
\hline & & & Ability praise & 1 \\
\hline & & & Effort praise & 3 \\
\hline \multirow[t]{3}{*}{ Teacher 2} & & & General praise & 8 \\
\hline & & & Ability praise & 1 \\
\hline & & & Effort praise & 2 \\
\hline \multirow[t]{3}{*}{ Teacher 3} & \multirow[t]{6}{*}{$\bar{B}$} & \multirow[t]{6}{*}{ Girls' Boarding } & General praise & 10 \\
\hline & & & Ability praise & 0 \\
\hline & & & Effort praise & 1 \\
\hline \multirow[t]{3}{*}{ Teacher 4} & & & General praise & 7 \\
\hline & & & Ability praise & 1 \\
\hline & & & Effort praise & 0 \\
\hline \multirow[t]{3}{*}{ Teacher 5} & \multirow[t]{6}{*}{$\mathrm{C}$} & \multirow[t]{6}{*}{ Mixed Day } & General praise & 2 \\
\hline & & & Ability praise & 0 \\
\hline & & & Effort praise & 1 \\
\hline \multirow[t]{3}{*}{ Teacher 6} & & & General praise & 12 \\
\hline & & & Ability praise & 1 \\
\hline & & & Effort praise & 6 \\
\hline \multirow[t]{3}{*}{ Teacher 7} & \multirow[t]{6}{*}{$\mathrm{D}$} & \multirow[t]{6}{*}{ Mixed Day } & General praise & 2 \\
\hline & & & Ability praise & 0 \\
\hline & & & Effort praise & 0 \\
\hline \multirow[t]{3}{*}{ Teacher 8} & & & General praise & 6 \\
\hline & & & Ability praise & 1 \\
\hline & & & Effort praise & 2 \\
\hline \multirow{3}{*}{\multicolumn{3}{|c|}{ Total }} & General praise & 57 \\
\hline & & & Ability praise & 5 \\
\hline & & & Effort praise & 15 \\
\hline \multicolumn{3}{|l|}{ Total praises } & & 77 \\
\hline
\end{tabular}


Based on the observation results in table 2 teachers of English in the four secondary schools used general praise 57 times and effort praise 15 times compared to ability praise 5 times. It is evident that teachers of English are conscious of the three categories of praise, but the majority used general praise.

Based on the types of praise used by teachers the study specifically looked at how learners were taught, learned and reinforced concurrently in all the four language skills that are, listening, speaking, reading and writing. The study found that teachers' reinforcement on the learners' four language skills influences their performance. They are expected to balance and strengthen their reinforcement on each learner's four skills. Learners actively listened by showing interest during the lesson by leaning forward in eagerness for more learning, deliberately making the effort of listening by avoiding distractions and focusing on the topic or sub-topic being taught, maintaining eye contact with the teacher in order to maintain concentration and observing the teachers' gestures and facial expressions which enhanced their understanding.

When learners read efficiently, the teacher praised those who only moved their eyes down the page from left to right. Those who moved their head from left to right as they went over every line and pointed at the words or sentences they read with a finger, pen or ruler were slow readers who received negative statements. Some learners read passages and poems aloud to the class. Teachers praised those who used their voice effectively by emphasising on important words or ideas with prominence, read audibly with sufficient volume and distinct enunciation, pronounced words correctly and varied the tone of their voice. Learners' written essays based on imaginative compositions and set texts were read and marked by teachers of English. They praised learners who used acceptable English language while paying attention to, legible handwriting, grammar rules, punctuation marks, tense and sentence construction correctly.

Regarding the learners' non-verbal communication reactions from their teachers' verbal praise reinforcement, the findings revealed that most learners were pleased. These non-verbal reinforcers included; when the teacher looked around the classroom, he/she secured the trust of his/her learners and got their personal attention. Secondly, the teacher listened to them. Thirdly, nodding of the head meant that he/she said "Yes". Fourthly, smiling showed that the teacher was friendly and pleasant. The teacher's smile and hold on his/her thumbs up gave learners approval. He/she used praise statements accompanied by a broad smile on his/her face. He/she wanted his/her learners to understand that he/she noticed when they did something right. When the teacher smiled genuinely at a learner, the learner smiled in return. The smile they got from their teacher positively changed their emotional state. This made his/her learners know that he/she valued their participation and contribution. It also helped them understand that their teacher was approachable, cooperative and trustworthy.

Besides, there was receiving claps from the teacher and all learners. In a particular instance, the teacher and all the class clapped for a learner who answered a question correctly. With this act, the dull learners also started participating in the classroom. They improved because classroom participation is crucial in learning. They felt that learning English is an exciting and happy experience. Also, physical touch by a pat on the back captured the learner's social attention; some teachers gave a bit of time to a learner when an answer seemed right at the moment. Finally, physical closeness applied by teachers of English suggested closeness of feeling and the learner was more likely to pay attention to what he/she was saying.

The results of this study acknowledged that those leaners who actively participated during the English language lessons were in a good mood happy, proud, grateful and contented. They implied that they had self-confidence, high selfesteem and a good teacher-student relationship. They thought more creatively and developed skills and mastery in the taught contents. They paid attention when the teacher taught them by; maintaining eye contact with the teacher which sustained their concentration. It also showed respect and gave the learner a feeling of comfort and genuine warmth during the lesson. Appropriate posture like keeping the head both horizontally and vertically, standing straight with squared shoulders, focused look and a level chin, portrayed learners' confidence. Further, their interest in the lesson was shown by leaning forward in eagerness for more learning. Nodding again proved that they were really listening, present and genuinely engaged. Contrastingly, some learners were dissatisfied by teachers" shaking of the head to say "No". They frowned when they were puzzled and raised eyebrows when they were surprised.

\section{Categories of Praise Used in the Classroom}

Table 3 shows the categories of praise used by teachers of English in classroom considering learners' reaction towards teachers' use of positive verbal reinforcement. 
Table 3: Categories of Praise Used in the Classroom

\begin{tabular}{|l|l|l|}
\hline Types of praise & Examples & Okay! \\
\hline General praise & Good! & Keep it up! \\
& Very good! & Well done! \\
& Excellent! & That's great! \\
& Correct! & Wonderful! \\
& Fine! & Fantastic! \\
& Right! & \\
& Yes, that is right! & \\
\hline Ability praise & I am sure you can do better than this. \\
\hline Effort praise & I believe you are able. & \\
& You have been working hard. \\
& Your improvement in English reflects the great effort you put in. \\
& You are improving. & \\
& A good trial! & \\
& Good effort! & \\
& You are on the right track.
\end{tabular}

Based on the results in table 3, the study found that general praise wasthe most commonly used in English language classrooms. It simply informs a learner that an answer is right, confirms correctness without adding distracting emotions, treats them as brilliant learners who prefer straight talk to overstatements and does not stir up emotions that might distract the learners from their intellectual work of learning. General praise typically expressed positive evaluations and feelings when the learners maintained or repeated English language behaviours. The following conversations indicate learners' reactions to teachers' of English general praises when they got the correct answers to questions.

"Yes. It informs me that an answer is correct." (Excerpt 1.)

"Yes. It treats me as an intelligent and dignified learner." (Excerpt 3.)

"Yes. It makes me feel proud of myself." (Excerpt 2.)

"Yes. It enabled me to stay on task, think actively and try my best." (Excerpt 6.)

Ability praise, as indicated in table 3, enables a learner to believe that he/she will be successful if he/she attempts to improve. Learners who reported receiving low levels of ability praise from their teachers had negative self-activities (English language behaviours) and said that they performed poorly in English subject. Ability praise had positive consequences, particularly when followed by improved performance. The findings of the study revealed that learners whose English language classroom had a positive learning environment and a positive relationship with their teacher of English stated that he/she gave them a great deal of ability praise. The following conversations designate learners' reactions to teachers' of English ability praises when they got the correct answers to questions.

"Yes. I feel confident and proud because it has made me develop a positive concept of myself as being competent and good in English." (Excerpt 2.)

"Yes. It accredits to my good performance." (Excerpt 6.)

"Yes. It enables me to stay on task, think actively and try my best."

"Yes. It empowers me to believe that I shall be successful if I attempt to improve."

"Yes. High levels of it boost my positivity in English classwork activities."

"Yes. It sets up my positive relationship with the teacher."

The results of the study in table 3 indicate that teachers of English used effort praise in the classrooms. Learners accepted to have a strong preference for receiving effort praise than ability and general praise. Learners provided with effort praise reported performing well following a decline in performance. Therefore, it means that more effort than ability praise should be given to them.

The findings demonstrated that effort praise was related to learners' relationship with their teachers of English. Learners who reported a positive relationship with their teachers of English affirmed that their teachers gave them extensive effort praise and little negative statements. Effort praise was given publicly, which most learners did not prefer as some preferred private praise. Effort praise should be given to all learners of all academic abilities for improvement or attainment of a target. It should also be given to appreciate weak leaners when they give correct answers. Learners praised for their honest efforts were encouraged to perform better. The following conversations show the learners' reactions to teachers' of English effort praises when they got the correct answers to questions. 
"Yes. It makes me perform well after a decline." (Excerpt 5.)

"Yes, I have developed a positive relationship with the teacher of English."

"Yes. It was done publicly when the whole class heard, but I preferred being done privately when I was alone."

"Yes. It allowed me to apply more effort when a topic or sub-topic was difficult for me."

"Yes. It enabled me to seek challenges in learning activities."

"Yes. It makes me set higher goals of scoring the best grade for myself." (Excerpt 4.)

"Yes, it enabled me to look at failure as an opportunity to learn."

"Yes, it motivated me to learn more."

Based on the findings of the study, effort praise directly affects learners' beliefs about their success. It leads to increased persistence, learning and improved motivation and performance.

\section{Teachers' Constant Use of Reinforcement in the Classroom}

Teachers of English were asked about their constant use of verbal praise reinforcement during the interview. Five responded that they use occasional praises while three use continuous praise. This study found out that teachers use both intermittent and continuous reinforcement schedules during instruction. This is in agreement with the study which was carried out by Kinyanjui et al., (2015) entitled classroom reinforcement schedules and their effectiveness in selected Kenyan primary schools. The study revealed that teachers use reinforcement schedules.

Schedule of reinforcement in this study involved a rule stating the basis on which reinforcements were delivered. Schedules of reinforcement were categorised by using time as a factor which is the period between which successive reinforcement was determined and by use of correct response as a factor which is the number of correct responses between which successive reinforcement was determined. Teachers reinforced their learners' correct or right responses. Schedules of reinforcement were represented by a specific arrangement of timers and counters.

Continuous reinforcement was given when a topic was introduced. Every instance of a correct response was given was positively reinforced. It led to high response rates and accelerated early performance. Extinction was experienced when no correct responses were reinforced. This happened during English lesson development when many learners had already mastered the content being taught by their teachers of English. On the other hand, intermittent reinforcement was given when not all correct responses were positively reinforced. In intermittent reinforcement, correct responses were maintained, and it was resistant to extinction. Variable interval and variable-ratio intermittent schedules were used in this study.

Variable interval reinforcement was given after varying lengths of time. The positive reinforcement in terms of verbal praise after correct responses were given at no specific time but varied randomly. Reinforcement was done at different times of the lesson. The following examples of reinforcement were given at time interval during a classroom observation. The time second language learners of English received reinforcement affected their performance. Table 4 is a sample of variable interview schedule that was used by a teacher of English in the classroom.

Table 4: Variable Interview Schedule

\begin{tabular}{|l|l|l|l|}
\hline Teacher & Praise & Time Interval \\
\cline { 3 - 4 } & & Seconds & Minutes \\
\hline 1 & Very good & & $11: 09 \mathrm{am}$ \\
& & & $11: 10 \mathrm{am}$ \\
& & & $11: 28 \mathrm{am}$ \\
\cline { 2 - 4 } & Correct & & $11: 08 \mathrm{am}$ \\
& & & $11: 13 \mathrm{am}$ \\
& & $11: 25 \mathrm{am}$ \\
\hline 2 & Good & $12: 40: 02 \mathrm{pm}$ & \\
& & $12: 40: 07 \mathrm{pm}$ & \\
& & $12: 40: 20 \mathrm{pm}$ & \\
& & $12: 40: 25 \mathrm{pm}$ & \\
\hline
\end{tabular}

Variable ratio reinforcement was given at random with no specific response interval. For example, at the $4^{\text {th }}$ correct response, reinforcement is given, followed at the $7^{\text {th }}$, again at $13^{\text {th }}$ correct response, reinforcement is given. For example; Excerpt 11 indicates a learner's response. "Yes, I did not receive praises to all the correct answers I got. Sometimes I get praised after my $4^{\text {th }}$ correct answer."

The findings indicated that classroom reinforcement schedules are more effective in learning ESL because they were given at any moment. In addition, some learners maintained a high level of academic performance because of the occasional praises they received from their teachers of English. 


\section{English Language Behaviour of Learners}

The results of the study indicated the things that learners do in the English language classroom that make their teachers of English reinforce them. The following conversations indicate learners' of English language behaviours that made their teachers of English reinforce them.

\section{Excerpt 9}

"There are some of the things that my learners do in the classroom that make me reinforce them. First, when they actively participate in a lesson, secondly when they ask questions when things are not understood and thirdly when they attempt to questions asked."

\section{Excerpt 10}

"Some of the things that my learners do in the English language classroom that makes me reinforce them include first, paying attention. Another factor is when they have all English learning materials like the dictionaries and English textbooks, novels and plays. Also, when they give correct answers during class discussions or lessons is another factor."

\section{Excerpt 11}

"Some of the things that my learners do in the English language classroom that make me reinforce them entails trying their best. Secondly, the contribution of their ideas during learning activities either in group discussions, presentations, dialogues, debates or role-playing and seeking out opportunities to learn more."

\section{Excerpt 12}

"They comprise of doing extra work, completing assignments and improving in their examination scores." From the above excerpts, teachers' verbal praise reinforcement intrinsically motivated learners which later increased the frequency of their desirable English language behaviours because of the positive experiences they got. Teachers' verbal praise managed English language behaviours of learners. Socio-education theory is relevant to the current study. Learners' self-confidence affected their attitudes towards English subject, their teachers and speakers of English language. It further facilitated English second language learning and performance. Confidence enabled learners to be in a feeling of relaxation, affirmation and at ease. Teachers of English had substantial effect on their learners' motivation because they are the ones with the most direct implication in second language instruction. The study also found out that teachers' use of positive reinforcement in the classroom promoted learners' attitude towards teachers of English and learning English language. The learners were more motivated to listen, speak, read and write when they had good relationships with their teachers of English. Effort was indicated by learners' persistent and consistent attempt to learn by attending to English language behaviours. Desire was approved by how much the learner wanted to strive to achieve their performance target and become competent in English as a second language. Positive affect was confirmed by motivated learners who displayed effort and desire to acquire and use English language. They were happy, proud and grateful in the efforts and achievement in English language skills when they were rightly merited by their teachers for the things they did well. This study also found out that attitude and motivation correlates with linguistic performance of English second language learners.

\section{Conclusion and Recommendations}

\section{Conclusion}

The study concludes that positive verbal praise reinforcement given by teachers of English in class works as a driving and motivational force which increases learners' probability to use and acquire competence in the English language. Reinforcement schedules are also effective. The time second language learners of English receive reinforcement as a result of the use and number of their correct responses affects their performance. In addition, reinforcement used by teachers in language classes greatly influences learners' performance in English. Positive verbal reinforcement allows learners to justify the benefits of learning English in school, encourages them, builds their self-esteem, self-confidence, a close teacher-student relationship and improves their performance in the four language skills (listening, speaking, reading and writing).

\section{Recommendations}

As indicated from the findings of the study that positive reinforcement could improve the learners' performance inthe English language in selected secondary in Nakuru town. It is necessary for secondary schools' administration to encourage teachers of English to acquaint themselves with positive verbal reinforcement techniques (general praise, ability praise and effort praise) which lead to learners' maintenance or repetition of the desired English language behaviours hence improve their performance. 
It is significant for learners to acquire all the four language skills (listening, speaking, reading and writing) in addition to being competent in using the English language in a variety of contexts in the modern world. As a result, reinforcing leaners to improve performance in English is to empower them to raise the standards of performance in national examinations and attain diverse educational, social, commercial, political and professional gains throughout their lives. The Ministry of education through curriculum developers should also come up with the current teachers' reinforcement policies inclined to the improvement of learners' competence and performance of English as a second language in secondary schools nationally. This research was based on how reinforcement could improve the learners' performance inthe English language in selected secondary schools in Nakuru town. The study recommends further research to be conducted in tertiary institutions and universities to examine the role of reinforcement on second language learners of English.

\section{References}

Abu-Mulhim, A. (2009). Re-evaluating the effectiveness of the audio-lingual method in teaching English to speakers of other languages.International Forum of Teaching and Studies, 5, 39-45.

Baumeister, R. F., Hutton, D. G., and Cairns, K. J. (1990).Negative effects of praise on skilled performance.Basic and Applied Social Psychology, 11, 131-148.

Boniecki, K.A., \& Moore, S. (2010). Breaking the silence: Using a token economy to reinforce classroom participation. Teaching of Psychology, 30(3), 224-227.

Brophy, J. (1981).Teacher praise: A functional analysis. Review of Educational Research, 51, 5-32.

Cazden, C.B. (2001). Classroom discourse: The language of teaching and learning (2 $2^{\text {nd }}$ ed.). Heinemann, Portsmouth.

Chalak, A. \&Kassaian, Z. (2010).Motivation And Attitudes Of Iranian Undergraduate EFL Students Towards Learning English. Journal of Language Studies, 10 (2), 37.

Chondhury,A.S.(2014).ClassroomroleofEnglishteachers. The traditional and innovative.Contemporary Online Language Education Journal, 1, 33-40.

Cohen, L., Manion, L., \& Morrison, K. (2005).A guide to teaching practise.Routledgefalmer, London.

Conroy,M.A.,Sutherland,K.S.,Snyder,A.,Al-Hendawi,M.,\&Vo,A.(2009).Creatinga positiveclassroomatmosphere:Teachers'useofeffectivepraiseandfeedback.Beyond Behaviour, 18(2), 18-26.

Crystal, D. (2015). English as a global language.Cambridge: Cambridge University Press.

Davies, L. (2003). Effective Praise.Retrieved from http://www.kellybear.com/ Teacher Articles/TeacherTip37.html

Deci, E. L., Koestner, R., \& Ryan, R. M. (2000).A meta-analytic review of experiments examining the effects of extrinsic rewards on intrinsic motivation.Psychological Bulletin, 125, 627-668.

Dhillion, J.,\&Wanjiru, J. (2013). Challenges and strategies for teachers and learners of English as a second language: The case of an urban primary school in Kenya. Journal of English Linguistics,3(2), 14-24.

Drabman, R. S., \&Lahey, B. B. (1974). Feedback in classroom behavoiur modification: Effects on the target and her classmates. Journal of Applied Behaviour Analysis, 7, 591-598.

Engin, A. O. (2009). Second language learning success and motivation.Social Behavior and Personality, 37, 10351042.

Folse, K. S. (2009). The art of teaching speaking: Research and pedagogy for the ESL/EFL classroom. University of Michigan Press, Ann Arbor.

Fromkin, V., Rodman, R., Hyams, N., Amberber, M., Cox, F., \& Thornton, R. (2018). An introduction to language. $\left(9^{\text {th }}\right.$ Ed.). South Melbourne, Vic.: Cengage Learning.

Gathua, J., Kiptiony, G., \&Somba, A. (2012).The challenges of teaching the revised English syllabus.Paper Presented at the $2^{\text {nd }}$ Annual Conference of Kabarak University, 2012. Retrieved from http://ir.kabarak.ac.ke/handle/123456789/253

Gomleksiz,M.(2001).Theeffectsofageandmotivationfactorsonsecondlanguageacquisition.F.Ü.SosyalBilimlerDergisi 11(2).

Hirst, E. S. J., Lockenour, F. M., \& Allen, J. L. (2019).Decreasing toe walking with differential reinforcement of other behaviour, verbal rules, and feedback. Education and Treatment of Children, 42(2), 185-199.

Huang,C. (2007).WhyDoUniversityStudentswanttolearnEnglish?Unpublished M.A. Thesis.Providence University.

Ilies,R.,\&Judge,T.A.(2005).Goalregulationacrosstime:Theeffectsoffeedbackandaffect. Journal of Applied Psychology, 90(3), 453-467.

Jin, G. (2008). Application of communicative approach in college English teaching.Asian Social Science, 4, 81-85.

Kaviti, L. (2018). The new curriculum of education in Kenya: A linguistic and education paradigm shift. International Journal of Novel Research in Education and Learning, 5(1), 15-27. 
Kinyanjui, M. W., Aloka, P. J. O., Mutisya, S., Ndeke, F. N., Nyang'ara, N. M. (2015). Classroom reinforcement schedules and their effectiveness in selected Kenyan primary schools. Journal of Educational and Social Research,MCSER Publishing, Rome-Italy,5(3), 267-277.

Kirui, C.C. (2007). The effect of teacher's use of praise and criticism in student's learning: A case study of Moiben Division of UasinGishu District. Unpublished M.A. Thesis.Njoro: Egerton University.

Kotut, J. B. (2016). Factors influencing performance of English as a subject in Kenya Certificate of Primary Education in Nakuru Town, East Sub-County, Kenya.Unpublished M.E. Project.Nairobi: University of Nairobi.

Lemlech, J. K. (1999).Classroom Management: Methods and techniques for elementary and secondary teachers ( $3^{\text {rd }}$ ed.).Prospect Heights, IL: Waveland Press.

Martin, G., \& Pear, J. J. (2016). Behaviour modification: What it is and how to do it. London: Psychology Press.

Ministry of Education, Science \& Technology.(2018). Nakuru Sub-County education management information system.Nakuru.

Njoroge, A. M. (2013). Language learner performance and the interpretation of teachers' written comments: A case study of pupils from selected primary schools in Nakuru Municipality, Kenya. Unpublished M.A. Thesis.Njoro: Egerton University.

Nnachi,R.O. (2007).Advancedpsychologyoflearning and scientificenquiries. Enugu:JohnJacob'sClassicPublishersLtd.

Nwankwo, O. C. (2002). Psychology of learning: The human perspective. Port Harcourt: Pam Unique Publishers.

Odima, L.E. (2015). Effect of teaching on acquisition of English language skills in primary schools in Busia County, Kenya.Unpublished M.E. Thesis.Nairobi: Kenyatta University.

Oduor, C. (2016). Students' perceived oral proficiency in English among Secondary School Students in Nakuru Town, Kenya.Published M.A. Thesis.Njoro: Egerton University.

Okpala, J. (2000). A study of two modes of reinforcement in the teaching and learning of English as a Second Language.Unpublished PhD Dissertation.Nsukka: University of Nigeria.

O'Leary, K. D., \& O'Leary, S. G. (1977). Classroom management: The successful use of behavior modification $\left(2^{\text {nd }}\right.$ ed.). Pergamon, New York.

Oyo, O. (2012). Impact of reward system in Kenyan Secondary Schools. Unpublished Master's thesis, Kenyatta University, Kenya.

Pintrich, P. R. and Schunk, D. H. 2002. Motivation in education: Theory, research and applications (2nd ed.). Upper Saddle River, NJ: Pearson Prentice Hall.

Reeves, A. (2017). Teacher perceptions, use, and knowledge of applied behaviour analysis-based techniques (Doctoral dissertation, Appalachian State University).

Slavin, R.(2009).Educationalpsychology:Theoryandpractice.Columbus, Ohio: PearsonInternational.

Stipek, D. (2002). Good instruction is motivating. In A. Wigfield\& J.S. Eccles (Eds.), Development of achievement motivation (pp. 309-332). Academic Press, San Diego.

Sun, Z. (2010).Language Teaching Materials and Learner Motivation.Journal of Language Teaching and Research, 1, 889-892.

Wafula, A. L., Malimbe, G. N., \&Kafu P. (2011). Classroom management: The state of positive reinforcement in secondary education in Kenya. International Journal of Current Research, 3(11), 38-70.

Wanzala, O. (2017).Daily Nation, Oct. $26^{\text {th }}$, p17.

Warden, C. A., \& Lin, H. J., (2000).Existence of integrative motivation in an Asian EFL setting. Foreign Language Annals, 33, 535-545.

Weiten, W. (2007).Psychology: Themes and variations. Belmont: Thomson Wordsworth.

Wheatley,R.K.,West,R.P.,Charlton,C.T.,Sanders,R.B.,Smith,T.G.,\&Taylor,M. J.(2009).Improving behaviour through differential reinforcement: A praise note system for elementary school students. Education and Treatment of Children, 32(4), 551-571.

Wheeler,J.J.(2009).Analysingthetreatmentefficacyofatechnical assistancemodelforprovidingbehaviouralconsultationtoschools.PreventingSchool Failure, $\quad 53(2), \quad 85-$ 88.Retrieved on February 16, 2018, from ERIC database.

Wilhelm, R.W., Contreras, G., \& Mohr, K.A.J. (2004).Barriers or frontiers: A bi-national investigation of Spanishspeaking immigrant students' school experiences. Paper presented at the Annual Convention of the American Educational Research Association, San Diego, CA.

Wyatt, M. (2009).Practical knowledge growth in communicative language teaching.The Electronic Journal for English as a Second Language, 13(2), 1-23.

Zua, L. (2008). Exploring the affective factors influencing teaching of spoken English.Retrieved from http://okarticle.com/html/Thesis/20080104/26.html. 